\title{
INDEXING ENTREPRENEURIAL SUCCESS OF FLORICULTURAL SMALL ENTERPRISES: EVIDENCE FROM SRI LANKA
}

\author{
K. K. A. Kiriveldeniya*, P. Sivashankar, M. S. Elapata, \\ R.P. Mahaliyanaarachchi, M. Esham \\ Department of Agribusiness Management, Faculty of Agricultural Sciences, Sabaragamuwa University of Sri \\ Lanka, Belihul Oya, Sri Lanka 70140 \\ *corresponding author: kalani.kiriveldeniya@gmail.com
}

\begin{abstract}
Commercialized agriculture shows better avenues in diversifying the rural livelihoods. Floriculture industry is an avenue to initiate successful small scale enterprises in a conducive environment. This paper explores the aspects in small scale floriculture industry to adapt strategies in rural development through indexing the success of floriculture small enterprises under eight dimensions. Both interviewer administrated questionnaire and in-depth interviews with key respondents were adapted in data collection. Findings indicate that the average entrepreneurial success index of the sample is 0.57 , meaning the average success level and $38 \%$ were very successful. Diversification (0.78), profitability $(0.68)$, social recognition $(0.61)$ are the dimensions that have the highest mean values and quality of supply or service (0.56), customer satisfaction $(0.45)$ and employee satisfaction $(0.27)$ had lower mean values. Middle age (34\%) and women (64\%) entrepreneurs' engagement in the industry was high. Time spent on the enterprise and labour usage depends on whether the business is their primary or secondary income activity. Floriculture small scale enterprises have been identified as a good income avenue for middle aged women in rural areas. However, rural development strategies need to address the requirement of how to develop the management skills of rural entrepreneurs as well for the sustainability of their enterprises.
\end{abstract}

Keywords: Agripreneurs, diversification, entrepreneurial success index, floriculture, rural development, small businesses

http://dx.doi.org/10.21776/ub.agrise.2020.020.3.1

Received 28 March 2020

Accepted 30 June 2020

Available online 29 July 2020

\section{INTRODUCTION}

Development of agriculture in emerging economies is vital to provide a sufficient income for their rural farming communities. Commercial agriculture has a potential in rural development with its transformation into profit-driven system out of subsistent agriculture. Profit driven production system has been seen as a way to achieve welfare gains through specialization, comparative advantage, economies of scale, regular interaction and exchange of ideas (Mathenge et al., 2010). The agripreneurship which is generally, sustainable, community-oriented, directly-marketed agriculture and the agripreneurs who have developed profitdriven entrepreneurial ventures within an agricultural environment is one ideal way of rural agriculture development (Nagalakshmi and Sudhakar, 2013).

Entrepreneurial venture creation is a universally identified and a well promoted strategy to achieve economic growth in developing countries (Gray, 2002: Kodithuwakku and Rosa, 2002). The entrepreneurs who create new ventures, face uncertainties in many ways (Kuratko and Hodgetts, 2004). They engage in the process by foreseeing the 
possible opportunities, gathering and combining necessary resources: time, energy and money while taking actions to ensure the success of their created ventures.

A developing country like Sri Lanka, requires high involvement of rural agripreneurs in agricultural venture creation. During 2017, agricultural contribution to national Gross Domestic Product (GDP) was 7.8\% (CBSL, 2017). Out of 21.2 million of country's population, $82 \%$ lives in rural areas. Out of $28.5 \%$ of country's farming community (SLDCS, 2014) majority live in rural areas and there is a considerable gap between their mean per capita income (Rs. 32,134) and per capita expenditure (Rs. 51,377) (SLDCS, 2016) where only $7.6 \%$ of the farmer income comes from agricultural activities (Ministry of Agriculture, 2019). Therefore, the agriculture sector needs to be developed to increase the returns from the sector and to act as a driver in rural empowerment (Davis, 2003).

Industry can be improved and modernized through diversification, commercialization and value addition (Ministry of Agriculture, 2019) leading towards the technological, structural, and institutional changes in the agriculture sector (Ulluwishewa, 1991). Empowering agripreneurs and encouraging others to engage in agribusinesses, is a solution to overcome the rural poverty by transforming traditional farming into profitable ventures (Weerahewa et al., 2004). Floriculture ventures provide such avenues for improvement through entrepreneurship.

Livelihood strategies (Carney, 1998; Scoones, 1998) promote entrepreneurial ventures at a wider range; however, need to be assessed for its long term suitability in rural development strategies. Given this, measuring the success of entrepreneurs is one method to understand the success. This paper investigates the level of entrepreneurial success of floriculture small businesses and current situation of floriculture industry in the Imbulpe DS division of Rathnapura District in Sri Lanka. Specific objectives of the study are to (a) investigate the socio-economic background of the floriculture entrepreneurs; (b) assess the level of entrepreneurial success of these small businesses; (c) identify the socio economic and demographic factors that affect the levels of success (d) identify the limitations and (e) adapt the SWOT analysis for the floriculture industry in Imbulpe DS division. According to Covin et al.,
2006, the relationship between a business's entrepreneurial orientation and its performance is still an under-explored topic even though the body of knowledge concerning it grew. This study is important as it highlights the hitherto untouched aspects of the small scale floriculture industry and helpful in designing rural development strategies in the areas where there is a conductive environment for floriculture growers.

\section{Entrepreneurial Success}

An entrepreneur is capable of recognizing any opportunity in a situation that is feasible to explore as a business opportunity and create job opportunities when others do not seem to identify the same (Kuratko and Audretsch, 2009). These explorations of opportunities can be a result of responding to the changes in the external environment (Drucker, 1995). Individuals capable of exploring opportunities possess certain leadership and managerial qualities to achieve their goals by managing and expanding their businesses (Quinn and Spreitzer, 1997). Floriculture is an agribusiness that can be easily adapted by entrepreneurs for rural empowerment. It is a high income generating agribusiness and its potential can be harnessed as an avenue for socioeconomic development of Sri Lanka (Padmini and Kodagoda, 2017).

Farm businesses are categorized as large and small agricultural businesses based on their volumes of operations and form of the organization (Uzun, 2005). Rural small businesses are more independent. Their local embeddedness and stability of customer base are high and competition is low compared to the urban businesses. However, small rural firms are limited in their ability to shape the external environment (Smallbone et al., 1999), but capable of turning limitations into opportunities, by adapting to local labour and market conditions in the context of limited externalization of their production (North and Smallbone, 1996: Rosairo and Potts, 2016). Existence of resource-munificent core regions, easy access to factors of production, information networks and markets create fruitful conditions to flourish even for the small rural businesses (Keeble et al., 2003). Therefore, small rural firms' survival will depend on their ability to respond to external environment's threats and opportunities (Smallbone et al., 1999). Hence, exploring the factors affecting for the successful ventures of entrepreneurs will provide better understanding to come up with 
evidence based approaches to improve the industry as well as to improve income distribution and poverty, rural development and export growth.

Though it is important to measure the extent of success of ventures by entrepreneurs, there is no direct way to measure it. The success might be multidimensional, and it may depend upon the inputs available to transform these inputs into multiple measures of entrepreneur success, subject to the influence of variables outside of the entrepreneur's control.

Entrepreneurial success means to which extent the entrepreneurs have considered themselves as successful (Narayan and Geethakutty, 2001) on their satisfaction about financial gains; income and profits, (Florin, Lubatkin, and Schulze, 2003) or on satisfaction about overall factors within the entrepreneur's business (Fried and Tauer, 2009). The determinants of factors leading to success and the characteristics of the successful entrepreneur have been extensively studied (Walker and Brown, 2004: Rogoff et al., 2009: Le and Raven, 2015: Díez-Martín et al., 2016). Several studies had tried to assess the entrepreneurial success including: meta-analysis (Unger et al., 2011), logit and probit regression (Harada 2003: Fried, and Tauer, 2015) and index calculation (Narayan and Geethakutty, 2006).

This current study has adapted Entrepreneurial Success Index (ESI) which was developed based on eight dimensions: profitability, employer satisfaction, social recognition, consumer satisfaction, product or brand recognition, capacity utilization, diversification and quality of supply and service.

Profitability is the degree to which entrepreneur perceives the enterprise as profitable and the extent of indebtedness or loan the entrepreneur has to pay back (Simpson et al., 2004; Chu et al., 2007). The extent to which the entrepreneur perceives how community/society, peer group, family and the individual consider the entrepreneur as a capable person or worthy citizen, is known as social recognition (Carter et al., 2003; Alvord et al., 2004). Consumer satisfaction is the degree of stability of consumer group and the amount and frequency of appreciation and complaints the entrepreneur receives (Jones et al., 2000; Sebora et al., 2009). Capacity utilization is the extent to which the individual utilizes the potential resources such as land, installed capacity of units etc. Related to his/her enterprise (Vinayagam, 1998; Ebiringa, 2011).

Diversification means number of branches the enterprises have and the number of main products or services supplied (Pyysiäinen et al., 2006; Clark, 2009; Vik and McElwee, 2011; Sharma, 2013). Product or brand recognition is the identification of the enterprise and the products/services in the local/state/national/international market, and the receipt of approval of authorities and receipt of recognition through awards, prizes etc. to the entrepreneur or the enterprise (Abimbola, 2001; Krake, 2005). Employer satisfaction is measured in terms of payment, job security, work environment and relation with the employer (Hughes, 2003; Simpson et al., 2004). The extent to which the consumers approve and appreciate the product and the services rendered by the entrepreneur (De Chiara and Minguzzi, 2002; Halkias et al., 2011) are considered as quality of supply/services.

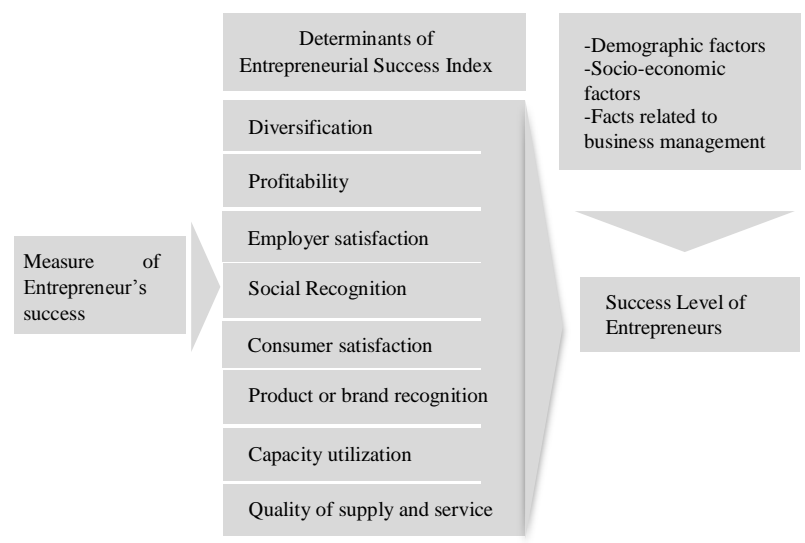

Figure 1. Conceptual framework

The above conceptual framework (Figure 1) illustrate the study focus on identifying the socioeconomic profile of floriculture entrepreneurs and to assess their success level based on literature review and interlinkage of the success level and their demographics and socio-economic profile. Profitability, employer satisfaction, social recognition, consumer satisfaction, product or brand recognition, capacity utilization, diversification and quality of supply and service were selected as the determinants of farmer's entrepreneurial success (Narayan and Geethakutty, 2006).

\section{RESEARCH METHODS}

This study was set up to measure the entrepreneurial success of floriculture growers in Rathnapura district's Imbulpe DS division, an area climatically 
conducive to cultivate wider range of foliage and flowering plants (Wijayathilake, 2017). Imbulpe DS is located in a rural area and most of villagers' income is through agriculture: fruits and vegetable, spices, and a significant amount are involved in floriculture, either as primary and secondary income that accounts for $6.5 \%$ of district farmer population (SLDCS, 2014). Ratnapura is the second highest poverty stricken district in Sri Lanka (SLDCS, 2017). Geographic and climatic conditions are in favor of floriculture and other inputs are easily available and connected to large scale floriculture growers.

Due to high dispersion of the study population and time limitation, 50 floriculture entrepreneurs were selected for the study. Since considerable number of floriculture entrepreneurs were not members of established floriculture societies, a snow-ball sampling technique was used to get a representative sample covering wider spatial distribution.

A pre-tested, interviewer administered questionnaire was used to collect data on demographics, socio-economic conditions and their perception about floriculture ventures under the eight dimensions. Detailed discussions with selected floriculture growers were also conducted. These discussions and field discussions assisted in explaining the results and the conducting the SWOT analysis.

Descriptive analysis was done with the primary data on demographics and socio-economic conditions of the respondents and also their usage of labour in business activities. Chi-square test was used to check the existence of any relationships among the socio-economics and demographics data of the floriculture entrepreneurs. Entrepreneurial Success Index (ESI) was developed: based on eight dimensions (Figure 1) where each dimension was assessed based five point Likert-scale questions. Under each dimensions, four questions were asked related to the dimensions (Narayan and Geethakutty, 2006).

The ESI was worked out using the following formula.

$$
\mathrm{ESI}=\sum_{\mathbf{i}=\mathbf{1}}^{\mathrm{k}} \frac{\mathbf{A}_{\mathbf{i}}}{\mathbf{P}_{\mathbf{i}}}
$$

Where;

ESI $=$ Entrepreneurial success index

$\mathrm{A}_{\mathrm{i}}=$ Actual score of $i^{\text {th }}$ dimension

$\mathrm{P}_{\mathrm{i}}=$ Potential score of $i^{\text {th }}$ dimension

$\mathrm{K}=$ Number of dimensions applicable
Source: Narayan and Geethakutty, (2006)

An ESI value of 1 means very high level of entrepreneurial success and an ESI value close to zero means lower level of success. Individuals were classified into four groups according to their ESI for detailed analysis using Dalenious Hodgese Rule (Dalenious and Hodgese, 1959). Then the Spearman's rank Correlation test was conducted to see the relationship between ESI value and the Socio-economic and demographics of the respondents. Finally, identification of the associated limitations and the SWOT analysis were conducted to explain the overall picture of floriculture industry in studied area.

\section{RESULTS AND DISCUSSION}

\section{Profile of Floriculture Entrepreneurs}

According to the sample, $64 \%$ of the floriculture entrepreneurs were females (Table 1). Most of the growers were in age categories of 31 to 40 years (34\%) and 41 to 50 years (22\%). Around 52\% percent of them claimed to have a formal education up to grade 8 , denoting that the sample was more likely to be less educated and biased towards lower education. However, majority (95\%) of the respondents had own decision making power regarding their business activities. Therefore, all the descriptive analysis hitherto presented reveal that, most of these women farmers are engaged in floriculture industry and they make a living out of this with their own decision making. This suggests most of the unemployed and housewives take part in floriculture industry (ICRW, 2009). Majority of these entrepreneurs were engaged in this business as a secondary income source $(76 \%)$ for their household expenditures. The rest (24\%) involve in this activity as a primary income source. So the floriculture is an industry that enable the empowerment of women in rural areas, especially the housewives. So they could contribute for their household food security and create jobs for rural community (Hlongwane et al., 2014)

Floriculture entrepreneurs in studied area had maintained 100-150 nursery level flower plants and foliage plants in growing bags at the beginning stage. Eventually, they had expanded their plantings into flower nurseries, flowering/foliage pot plants, cut flower/foliage plants or sometimes a combination of all together with vegetable plants and spices at small scale. Most of the farmers sell 
nursery plants and pot flower plants. Only few conduct businesses on cut flower sales. Stock buyers and tourists who pass the Imbulpe DS area were the main buyers of these agripreneurs.
Thus, most of the ventures are located near the main road and for the ones located far away were less likely to have a big customer base at the initial stage. Few of them have expanded towards the sales of raw material. Some well-experienced agripreneurs who possess a good connection with market value chain, sell around 1000 nursery plants per week and earn nearly Rs. 100,000 per week.

Table 1. Socio-Economic of the sample

\begin{tabular}{|c|c|c|c|}
\hline Criteria / Category & Percentage & Criteria / Category & Percentage \\
\hline Age & & Education level & \\
\hline 21 to 30 years & 22 & Up to grade 8 & 52 \\
\hline 31 to 40 years & 34 & Up to ordinary level & 22 \\
\hline 41 to 50 years & 22 & Up to advanced level & 20 \\
\hline 51 to 60 years & 12 & Diploma level & 04 \\
\hline$>60$ years & 10 & Graduate level & 02 \\
\hline Gender & & $\begin{array}{l}\text { Previous } \\
\text { floriculture }\end{array}$ & \\
\hline Female & 64 & Yes & 88 \\
\hline Male & 36 & No & 12 \\
\hline $\begin{array}{l}\text { Income from floriculture } \\
\text { venture }\end{array}$ & & How the knowledge was gained & \\
\hline Primary income & 24 & $\begin{array}{r}\text { Programs of floriculture } \\
\text { society }\end{array}$ & 66 \\
\hline Secondary income & 76 & Self-learning & 08 \\
\hline Continuity of venture & & From government institutions & 10 \\
\hline Conduct continuously & 74 & From diploma & 04 \\
\hline Discontinuous & 26 & From school education & 12 \\
\hline Decision making power & & $\begin{array}{l}\text { Time spend on business } \\
\text { activities }\end{array}$ & \\
\hline Owner & 94 & Less (1- <6 hours) & 62 \\
\hline Family influence & 4 & Moderate (6 to 12 hours) & 18 \\
\hline $\begin{array}{r}\text { Market and other external } \\
\text { factors }\end{array}$ & 2 & High (>12 hours) & 20 \\
\hline \multirow[t]{4}{*}{ Labour usage } & & Age of venture & \\
\hline & 76 & 1 to 6 years & 74 \\
\hline & 24 & 7 to 12 years & 12 \\
\hline & & $\begin{array}{r}12 \text { to } 18 \text { years } \\
\text { More than } 18 \text { years }\end{array}$ & $\begin{array}{c}12 \\
2\end{array}$ \\
\hline
\end{tabular}

\section{Source: Survey data}

Some maintain 100-150 plants and found it difficult to find a market with a decent price. Wellestablished entrepreneurs had been horizontally integrated at the upper stream by providing raw materials including mother plants for new entrepreneurs with a promise of buying back the quality plants. The presence of grower clusters in floriculture industry enable better access to resources, markets and long term-survival than when they operate in isolation (Reid, and Carroll, 2005).
As majority of the respondents $(76 \%)$ conduct their floriculture ventures as a secondary income source, most of them $(62 \%)$ stated they spend less time ( 1 to 6 hours per day) for their business activities (Table 1). In the sampled population, $76 \%$ of agripreneurs were using any type of labor they could obtain and afford. Most of them (70\%) use family labour as a mean to cut down the excessive cost of production (Alabi et al., 2018). Though, the sample was biased towards female entrepreneurs, participation of female family labour $(77 \%)$ and use of female labour hours (281 hours) were 
significantly higher than participation of male family labour (33\%) and use of male labour hours (119 hours) (Table 2). However, 14\% and $16 \%$ of respondents were using part-time and full-time labour for their farming activities, respectively. Even in this measure, the female labour participation was higher than male labour participation (Females: $73 \%$ full time, $75 \%$ part-time; Male: $27 \%$ fulltime and 25\%-part time). Unemployed women and housewives in this area tend to adapt this type of business or labor work to support their household economy. Women are motivated by both their perception of values and perception of entrepreneurship towards floricultural activities (Fried and Tauer, 2009). Among the respondents, $88 \%$ had knowledge about the industry when they entered to the floriculture industry through programmes conducted by village level floriculture societies. Programmes by the floriculture society had been their main knowledge source which was economically feasible for themselves and also instills motivation for start-ups. So far, $76 \%$ of the respondents had been able to do the business continuously without breaks. However, most of their (74\%) businesses were aged between 1-6 years. Only $25 \%$ of the businesses were older than six years.
The people who conducted the business as a secondary income source were significantly associated with spending less time and vice versa (Table 3). These floriculture businesses showed a significant association with the age of the businesses and hiring of additional labour as well. Young businesses were mostly using family labour or no labour, whereas mature businesses used hired labor. Further, when the owners spend more time with the businesses they hire less labor and vice versa

Table 2. Labour usage by floriculture entrepreneurs in the study area.

\begin{tabular}{|c|c|c|c|c|}
\hline \multirow[t]{2}{*}{$\begin{array}{l}\text { Labour } \\
\text { type }\end{array}$} & \multicolumn{2}{|c|}{$\begin{array}{c}\text { Gender } \\
(\%)\end{array}$} & \multicolumn{2}{|c|}{$\begin{array}{r}\text { Labour } \\
\text { hours (hrs) }\end{array}$} \\
\hline & Male & Female & Male & Female \\
\hline $\begin{array}{l}\text { Family } \\
\text { labour }\end{array}$ & 33 & 77 & 119 & 281 \\
\hline $\begin{array}{l}\text { Full-time } \\
\text { labour }\end{array}$ & 27 & 73 & 032 & 138 \\
\hline $\begin{array}{l}\text { Part-time } \\
\text { labour }\end{array}$ & 25 & 75 & 041 & 127 \\
\hline
\end{tabular}

Table 3. Chi Square test results with business activities

\begin{tabular}{lll}
\hline \multicolumn{1}{c}{ Criteria } & $\chi^{2}$ value & $\mathrm{p}$ value \\
\hline Primary/secondary income source versus continuity of venture & 2.561 & 0.110 \\
Income source versus gender & 1.343 & 0.246 \\
Continuity versus gender & 1.273 & 0.259 \\
Income source versus time spend on activities & 17.264 & 0.000 \\
Time spent on activities versus labor hiring & 3.714 & 0.156 \\
Labor hiring versus continuity & 2.774 & 0.096 \\
Labor hiring versus age of the venture & 2.619 & 0.454 \\
Labour type vs age of the venture & 64.998 & 0.000 \\
Time spent on activities versus labour type & 30.438 & 0.002 \\
\hline
\end{tabular}

Note: significant at $\mathrm{p}=0.05$ level

Source: Survey data

\section{Level of success among the floriculture entrepreneurs}

Findings of the assessment of success of floriculture farmers denote that, ESI of the respondents ranged from 0.28 to 0.75 (Table 4) and the average ESI values was 0.57 . On average, the sample population's floriculture businesses were thriving. Out of the sample, $38 \%$ and $26 \%$ of the respondents fell into the very high and high level of success based on the ESI score respectively (Table 4).

Table 4. Classification and distribution of floriculture entrepreneurs based on ESI

\begin{tabular}{llcc}
\hline No & Category & ESI Score range & $\begin{array}{c}\text { Percentage } \\
(\%)\end{array}$ \\
\hline 1 & Very high & $>0.64$ & 38 \\
2 & High & $0.52-0.63$ & 26 \\
3 & Medium & $0.40-0.51$ & 16 \\
\hline
\end{tabular}




\begin{tabular}{llll}
\hline 4 & Low & $0.28-0.39$ & 20 \\
\hline
\end{tabular}

Source: Survey data

According to their responses, this level of success was achieved mainly because of the capability of the industry to create profit, diversified business opportunities, and the social recognition they had earned as floriculturists within the area as those floricultural industries do not carry any taboos in the locality so social recognition was high.

Table 5. Mean values of the dimensions of entrepreneurial success

\begin{tabular}{ll}
\hline \multicolumn{1}{c}{ Dimension } & Mean \\
\hline Diversification & 0.78 \\
Profitability & 0.68 \\
Social recognition & 0.61 \\
Capacity utilization & 0.60 \\
Product or brand recognition & 0.60 \\
Quality of supply/services & 0.56 \\
Customer satisfaction & 0.45 \\
Employer satisfaction & 0.27 \\
\hline
\end{tabular}

Source: Survey data

Diversification (0.78), profitability (0.68), social recognition (0.61) are the dimensions that had highest mean values among the entrepreneurial success dimensions (Table 5). Their capacity utilization and product/brand recognition had similar mean values (0.6). Quality of supply or service had a mean value of 0.56. Employee and customer satisfaction had mean values of 0.27 and 0.45 respectively. Diversification of businesses towards supply of different flowering and foliage plants in different varieties from nursery level to flowering stage, and raw materials sales had enabled them to expand the customer groups they serve.

They claimed their floriculture business activities were moderately profitable in terms of income, and manageability of debts while gaining profits for themselves. Those reasons made them to be confident to continue their businesses in floriculture industry as they have earned this level of efficiency in production with few resources, with a low budget, contributing limited hours limited time spent and limited labour contribution (Fried and Tauer, 2009). Therefore, entrepreneurs claimed that they have built successful floriculture ventures in Imbulpe DS even with limited resources and operating at a lower cost.

Owning a business, had earned a moderate level of recognition among the society where their participation in social activities was appreciated and valued within their villages (Baron, 2000). Their level of social competence which came with success of the businesses, was very useful for their businesses when attempted to strengthen the value chain activities. Respondents had a moderate level of capacity utilization under the available land, equipment and resources. This caused $26 \%$ of entrepreneurs to gain a moderate level of success.

Table 6. Correlation test results on relationship between ESI and the socio-economic characteristics

\begin{tabular}{|c|c|c|c|}
\hline Category & $\begin{array}{l}\text { Correlation } \\
\text { coefficient }\end{array}$ & $\mathrm{p}$ value & Remark \\
\hline Age & 0.92 & 0.02 & High positive effect \\
\hline Gender & 0.65 & 0.06 & Not significant \\
\hline Level of education & 0.58 & 0.00 & Positive moderate effect \\
\hline $\begin{array}{l}\text { Extent of the land utilized in } \\
\text { business activities }\end{array}$ & -0.68 & 0.00 & Negative moderate effect \\
\hline $\begin{array}{l}\text { No. of years entrepreneur has } \\
\text { been continuing the venture }\end{array}$ & -0.61 & 0.00 & Negative moderate effect \\
\hline $\begin{array}{l}\text { Entrepreneur having } \\
\text { knowledge before initiating } \\
\text { the venture }\end{array}$ & -0.38 & 0.15 & Not significant \\
\hline $\begin{array}{l}\text { Source of knowledge } \\
\text { regarding floriculture }\end{array}$ & 0.51 & 0.00 & Positive moderate effect \\
\hline $\begin{array}{l}\text { Labour usage in venture } \\
\text { activities }\end{array}$ & 0.25 & 0.83 & Not significant \\
\hline
\end{tabular}

Note: significant at $\mathrm{p}=0.05$ level 
Optimum use of available land according to the size of their business operations, use of available simple equipment and simple structures to shade the plants had lower mean values. Limited utilization of resources was mainly a result of the entrepreneurs' limited financial capabilities.

Production recognition was moderate in their current markets and bulk sales come from faraway customers. Entrepreneurs had moderate level quality of supplying their products and services. This is a result of their incapability to serve for a wider range of customer group due to the financial and resource limitations. Further, exhibitions held under the supervision of floriculture societies had been moderately supportive to recognize new buyers. However, the mean values of entrepreneurs' satisfaction about themselves, their own business operations and their current financial and nonfinancial conditions were lower.

According to the respondents, diversifying their pot flower cultivation into a range of varieties has been a good strategy to earn a better income from their businesses (Mishra et al., 2004). This may be also considered as a strategy to overcome climate variability (Weerahewa et al, 2012). Since the ventures are small to medium scale, diversification enables them to serve for a wider range of customers and to overcome vulnerabilities. Farmers cultivate multiple varieties of flowering and foliage plants. In addition, potential agripreneurs sell raw materials. Further, binomial climatic condition in Imbulpe area has been an advantage on diversifying these cultivations. Further, diversification has been supportive for the success of these entrepreneurs' floriculture ventures.

Mean analysis reveals that ground level development and supportive actions needs to be considered to move beyond average success level. Supportive actions are required for small scale entrepreneurs to gain information, to obtain trending flowering and foliage mother plants, and knowledge on how to produce a quality product to fulfil the customer demands while using minimum level gardening equipment in planting activities. At this juncture, sufficient financial sources are a necessity. Entrepreneurs needs to be knowledgeable in business management, designing and development of their own brand, and promotional activities to promote their products. Finally, they have to be socially recognized as entrepreneurs and employment creators. These measures will retain them in the industry with a higher possibility of expansion and development. Support of the local authorities are needed to create a profitable market for the products of these emerging small-scale floriculture businesses. Furthermore, the findings suggested that the entrepreneurs have to pay more attention on employer satisfaction and consumer satisfaction since they affected the success negatively. In dimensions of capacity utilization, quality of product/service and product/ brand recognition further attention is required as they contributed moderately towards success. Therefore, it is necessary to implement strategies to increase the product/ brand recognition and to improve capacity utilization and quality of supply and service for further success of their ventures.

\section{Major Constraints in the floriculture industry} Identification of major constraints enable the development strategies to be focused on overcoming these identified constraints. Among the major issues faced by the floriculture entrepreneurs high price of raw materials (Table 7) especially when obtaining commercially demanding healthy mother plants had limited their ability of expanding the business. Difficult environmental conditions exist within the area, difficulties in approaching a profitable market for sales, limited self-finance for fixed and working capital and their lack of know-how about the modern technology have caused limited growth within the industry. In that case, by encouraging the medium and large scale entrepreneurs to engage with small scale entrepreneurs to buy nursery plant stocks while providing necessary mother-plants, raw materials and know-how can be used as mutual development strategy of the floriculture entrepreneurs in Imbulpe DS division. Also, government and non-government agencies should be focusing on above factors when conducting the development programmes.

Table 7. Identification and ranking of major problems associated within the floriculture industry

\begin{tabular}{lll}
\hline Problem & Score & Rank \\
\hline $\begin{array}{l}\text { High price of raw materials } \\
\begin{array}{l}\text { Difficult environmental } \\
\text { conditions }\end{array}\end{array}$ & 43 & 01 \\
$\begin{array}{l}\text { Difficulties in approaching a } \\
\text { profitable market for sales }\end{array}$ & 39 & 03 \\
$\begin{array}{l}\text { Limited self-finance for fixed } \\
\text { and working capital }\end{array}$ & 35 & 04 \\
\hline
\end{tabular}




\begin{tabular}{lcc}
\hline $\begin{array}{l}\text { Lack of know-how about } \\
\text { modern technology }\end{array}$ & 33 & 05 \\
Government policies & 02 & 06 \\
\hline
\end{tabular}

Source: Survey data

\section{SWOT ANALYSIS}

Well-planned policy development can be established with a proper assessment of strengths and weaknesses existing in the internal environment and the opportunities and threats existing in the external environment. Strategies can be developed and implemented to utilize the opportunities in external environment while eliminating/minimizing the threats to maximize the strengths and minimizing the weaknesses of small floriculture businesses in Imbulpe DS division. Following strengths, weaknesses, opportunities and threats (Table 8) were identified based on the field survey and in-depth interviews conducted with the floriculture entrepreneurs.

Table 8. SWOT analysis about small floriculture businesses in Imbulpe DS division

\begin{tabular}{|c|c|c|c|}
\hline Strengths & Weaknesses & Opportunities & Threats \\
\hline $\begin{array}{l}\text { Startup possible with } \\
\text { own experience / } \\
\text { knowledge in } \\
\text { farming, with } \\
\text { minimum resources }\end{array}$ & $\begin{array}{l}\text { Farther the business } \\
\text { located from main } \\
\text { road lesser the } \\
\text { customer approach }\end{array}$ & $\begin{array}{l}\text { Government and non- } \\
\text { government programmes } \\
\text { to support the floriculture } \\
\text { entrepreneurs }\end{array}$ & $\begin{array}{l}\text { Economies of scale of } \\
\text { large businesses } \\
\text { (technology, cost, market } \\
\text { share) }\end{array}$ \\
\hline $\begin{array}{l}\text { Availability of family } \\
\text { labour }\end{array}$ & $\begin{array}{l}\text { Lack of skilled } \\
\text { labour }\end{array}$ & $\begin{array}{l}\text { Location advantage to } \\
\text { reach more and new } \\
\text { customers }\end{array}$ & $\begin{array}{l}\text { Time to time occurred } \\
\text { adverse climatic } \\
\text { conditions }\end{array}$ \\
\hline $\begin{array}{l}\text { Adaptability as an } \\
\text { additional income } \\
\text { source }\end{array}$ & $\begin{array}{l}\text { Lack of ability to } \\
\text { explore the new } \\
\text { market } \\
\text { opportunities }\end{array}$ & $\begin{array}{l}\text { Possibility of adapt as an } \\
\text { employment generating } \\
\text { women group } \\
\text { empowerment method }\end{array}$ & $\begin{array}{l}\text { Absence of proper crop } \\
\text { insurance for } \\
\text { infrastructure and } \\
\text { flowering crops }\end{array}$ \\
\hline $\begin{array}{l}\text { Trend of small-holder } \\
\text { engagement in } \\
\text { floriculture }\end{array}$ & $\begin{array}{l}\text { Limited production } \\
\text { limitsto meet } \\
\text { customer demand }\end{array}$ & $\begin{array}{l}\text { Ability to develop and } \\
\text { promote a recognizable } \\
\text { unique brand for the } \\
\text { floriculture products }\end{array}$ & $\begin{array}{l}\text { Discontinuity of } \\
\text { government and non- } \\
\text { government supportive } \\
\text { programmes }\end{array}$ \\
\hline Less labour intensity & $\begin{array}{l}\text { Poor management } \\
\text { skills }\end{array}$ & $\begin{array}{l}\text { Increasing customer } \\
\text { awareness/demand }\end{array}$ & $\begin{array}{l}\text { Unfavorable government } \\
\text { rules and regulations }\end{array}$ \\
\hline \multirow[t]{2}{*}{$\begin{array}{l}\text { Diversification within } \\
\text { the industry }\end{array}$} & $\begin{array}{l}\text { Unifomity and } \\
\text { quality aspects of } \\
\text { flowers }\end{array}$ & $\begin{array}{l}\text { Conducive climate, soil } \\
\text { and to produce wider } \\
\text { range of flowering plants }\end{array}$ & $\begin{array}{l}\text { Absence of regular } \\
\text { customer group }\end{array}$ \\
\hline & & $\begin{array}{l}\text { Vertical integration with } \\
\text { small scale entrepreneurs } \\
\text { Loan facilities from } \\
\text { Samurdhi Loan schemes } \\
\text { Ability to serve wide } \\
\text { range of customer group }\end{array}$ & \\
\hline
\end{tabular}

Source: Survey data

\section{CONCLUSION}

The study assessed the success of small scale floriculture enterprises and the factors affecting their success under socio-economic and demographic factors as well the factors related to venture management. Findings indicate that studied sample has marginal average success level which is 0.57 . Cumulative of the higher ESI strata indicated that more than half of the sample $(64 \%)$ are successful in business and $16 \%$ and $20 \%$ scored medium and lower levels of success, respectively. This result suggest that each cluster require different assistance. The $20 \%$ of lower performing cohorts have to be trained or assisted based on the shortcoming they have. And, the high performers need the guidance to tap the export market through intermediaries in the market. Further, the low performers could be linked 
with high performers to start up the support they needed.

Results point out that it was the middle aged women with minimum formal education take part in small scale floriculture enterprises in the studied area. Their main determination was to support the family economy by engaging in businesses that promise a long term economic growth with minimum resource utilization. Since most of them are less educated and middle aged women, it is vital that they are being made aware about proper credit and financing facilities (financial literacy). This has been cited as one of the major limitations. Profitability, social recognition and diversification had been the major reasons of success. This success is also affected by efficient resource utilization of entrepreneurs with ventures at initial stage. Their limitations in financial, environmental, technological and market approachability have hindered the ability to expand into a profitable venture.

Small scale floriculture enterprises have been identified as a field that has high women contribution in household empowerment. Vertical integration among the less successful to high successful floriculture entrepreneurs was also identified as a possible measure in collective empowerment in this area. And finally, the study has emphasized the need of addressing the limitations exist in the industry by the supportive government and non-government organizations in the studied area. Adapting microfinancing solutions to purchase the necessary raw materials, branding and brand promotion through exhibitions and name boards also can be adapted at community level as a remedy to overcome the limitations identified from the study.

\section{REFERENCES}

Abimbola, T. (2001). Branding as a competitive strategy for demand management in SMEs. Journal of research in marketing and entrepreneurship, 3(2), 97-106.

Alabi, D. L., Akintola, O. M., \& Famakinwa, M. (2018). Perception of Maize Processors Towards Utilization of Maize Value Addition Techniques: Implications for Rural Entrepreneurship Development-A Study in Nigeria. Journal of Agricultural Sciences Sri Lanka, 13(2), pp.141-152. DOI: http://doi.org/10.4038/jas.v13i2.8338
Alvord, S. H., Brown, L. D., \& Letts, C. W. (2004). Social entrepreneurship and societal transformation: An exploratory study. The journal of applied behavioral science, 40(3), 260-282.

Baron, R. A. (2000). Psychological perspectives on entrepreneurship: Cognitive and social factors in entrepreneurs' success. Current directions in psychological science, 9(1), 1518.

Carney, D. (1998). Sustainable livelihoods. Sustainable Livelihoods: What contribution can we make.

Carter, N. M., Gartner, W. B., Shaver, K. G., \& Gatewood, E. J. (2003). The career reasons of nascent entrepreneurs. Journal of Business Venturing, 18(1), 13-39.

Central Bank of Sri Lanka, (2017). National Output, Expenditure and Income. Retrieved from https://www.cbsl.gov.lk/sites/default/files/cb slweb_documents/publications/annual_repor t/2017/en/6_Chapter_02.pdf.

Chu, H. M., Benzing, C., \& McGee, C. (2007). Ghanaian and Kenyan entrepreneurs: A comparative analysis of their motivations, success characteristics and problems. Journal of developmental entrepreneurship, 12(03), 295-322.

Clark, J. (2009). Entrepreneurship and diversification on English farms: Identifying business enterprise characteristics and change processes. Entrepreneurship and Regional Development, 21(2), 213-236.

Covin, J. G., Green, K. M., \& Slevin, D. P. (2006). Strategic process effects on the entrepreneurial orientation-sales growth rate relationship. Entrepreneurship theory and practice, 30(1), 57-81.

Dalenius, T., \& Hodges Jr, J. L. (1959). Minimum variance stratification. Journal of the American Statistical Association, 54(285), 88-101.

Davis, J. R. (2003). The rural-non-farm economy, livelihoods and their diversification: Issues and options. Livelihoods and their Diversification: Issues and Options (July 2003).

De Chiara, A., \& Minguzzi, A. (2002). Success factors in SMEs' internationalization processes: An Italian investigation. Journal of small business management, 40(2), 144153.

Díez-Martín, F., Blanco-González, A., \& PradoRomán, C. (2016). Explaining nation-wide differences in entrepreneurial activity: A legitimacy perspective. International Entrepreneurship and Management Journal, 12(4), 1079-1102. 
Drucker, P.F. (1995). The theory of business, Harvard Business Review, 75(5), 95-104.

Ebiringa, O. T. (2011). Entrepreneurship venturing and Nigeria's economic development: The manufacturing sector in focus. International. Journal of Business Management \& Economic Research, 2(6), 376-381.

Florin, J., Lubatkin, M., \& Schulze, W. (2003). A social capital model of high-growth ventures. Academy of Management Journal, 46(3), 374-384.

Fried, H. O., \& Tauer, L. W. (2009). Understanding the entrepreneur: An index of entrepreneurial success.

Fried, H.O. and Tauer, L.W. (2015). An entrepreneur performance index. Journal of Productivity Analysis, 44(1), 69-77.

Gray, C. (2002). Entrepreneurship, resistance to change and growth in small firms. Journal of Small Business and Enterprise Development.

Okpara, J. O., Halkias, D., Nwajiuba, C., Harkiolakis, N., \& Caracatsanis, S. M. (2011). Challenges facing women entrepreneurs in Nigeria. Management Research Review.

Harada, N. (2003). Who succeeds as an entrepreneur? An analysis of the post-entry performance of new firms in Japan. Japan and the world economy, 15(2), 211-222.

Hlongwane, J. J., Ledwaba, L. J., \& Belete, A. (2014). Analyzing the factors affecting the market participation of maize farmers: A case study of small-scale farmers in greater Giyani Local Municipality of the Mopani District, Limpopo Province. African journal of agricultural research, 9(10), 895-899.

Hughes, K. D. (2003). Pushed or pulled? Women's entry into self- employment and small business ownership. Gender, Work \& Organization, 10(4), 433-454.

International Centre for Research on Women, (2009). Innovation for Women's Empowerment and Gender Equality, Retrieved from http://www. icrw.org.

Jones, E., Roberts, J. A., \& Chonko, L. B. (2000). Motivating sales entrepreneurs to change: a conceptual framework of factors leading to successful change management initiatives in sales organizations. Journal of Marketing Theory and Practice, 8(2), 37-49.

Keeble, J. J., Topiol, S., \& Berkeley, S. (2003). Using indicators to measure sustainability performance at a corporate and project level. Journal of Business Ethics, 44(2-3), 149-158.

Kodithuwakku, S. S., \& Rosa, P. (2002). The entrepreneurial process and economic success in a constrained environment. Journal of Business Venturing, 17(5), 431-465.

Krake, F. B. (2005). Successful brand management in SMEs: a new theory and practical hints. Journal of Product \& Brand Management.

Kuratko, D. F., \& Audretsch, D. B. (2009). Strategic entrepreneurship: exploring different perspectives of an emerging concept. Entrepreneurship theory and practice, 33(1), 1-17.

Kuratko, D. F., \& Hodgetts, R. M. (2004). Entrepreneurship: Process. Practice, 6.

Le, Q. V., \& Raven, P. V. (2015). Woman entrepreneurship in rural Vietnam: Success and motivational factors. The Journal of Developing Areas, 57-76.

Mathenge, M., Place, F., Olwande, J., \& Mithoefer, D. (2010). Participation in agricultural markets among the poor and marginalized: analysis of factors influencing participation and impacts on income and poverty in Kenya. Unpublished Study Report Prepared for the FORD Foundation.

Ministry of Agriculture, (2019). Agriculture Sector Modernization Project. Retrieved from http://www.agrimin.gov.lk/web/index.php/p roject/12-project/841-agriculture-sectormodernization-project

Mishra, A. K., El-Osta, H. S., \& Sandretto, C. L. (2004). Factors affecting farm enterprise diversification.

Nagalakshmi, T., \& Sudhakar, A. (2013). Agripreneurs: a case study of Dharmapuri farmers. International Journal of Science and Research, 2(8), 208-214.

Narayan, S. S., \& Geethakutty, P. S. (2006). Level of entrepreneurial success among women entrepreneurs in agribusiness. Journal of Tropical Agriculture, 41, 41-44.

North, D., \& Smallbone, D. (1996). Small business development in remote rural areas: the example of mature manufacturing firms in Northern England. Journal of Rural Studies, 12(2), 151-167.

Padmini, S. M. P. C., \& Kodagoda, T. D. (2017). Present status and future scope of floriculture industry in Sri Lanka and its potential in women empowerment. Sri Lanka Journal of Social Sciences, 40(1).

Pyysiäinen, J., Anderson, A., McElwee, G., \& Vesala, K. (2006). Developing the entrepreneurial skills of farmers: some myths explored. International Journal of Entrepreneurial Behavior \& Research.

Quinn, R. E., \& Spreitzer, G. M. (1997). The road to empowerment: Seven questions every leader 
should consider. Organizational dynamics, 26(2), 37-49.

Reid, N., \& Carroll, M. (2005). Using Cluster-based Economic Development to Enhance the Economic Competitiveness of Northwest Ohio's Greenhouse Nursery Industry. In Papers and proceedings of applied geography conferences (Vol. 28, p. 309). [np]; 1998.

Rogoff, E. G., Lee, M. S., \& Suh, D. C. (2004). "Who done it?" Attributions by entrepreneurs and experts of the factors that cause and impede small business success. Journal of Small Business Management, 42(4), 364-376.

Rosairo, H. R., \& Potts, D. J. (2016). A study on entrepreneurial attitudes of upcountry vegetable farmers in Sri Lanka. Journal of Agribusiness in Developing and Emerging Economies.

Scoones, I. (1998). Sustainable rural livelihoods: a framework for analysis.

Sebora, T. C., Lee, S. M., \& Sukasame, N. (2009). Critical success factors for e-commerce entrepreneurship: an empirical study of Thailand. Small Business Economics, 32(3), 303-316.

Sharma, Y. (2013). Women entrepreneur in India. IOSR Journal of Business and Management, 15(3), 9-14.

Simpson, M., Tuck, N., \& Bellamy, S. (2004). Small business success factors: the role of education and training. Education+ Training, 46(8/9), 481-491.

Smallbone, D., North, D., \& Kalantaridis, C. (1999). Adapting to peripherality: a study of small rural manufacturing firms in northern England. Entrepreneurship \& Regional Development, 11(2), 109-127.

Sri Lanka Department of Census and Statistics, (2014). Census of population-2014, Retrieved from http://www.statistics.gov.lk/agriculture/Publ ications/Ratnapura\%20SH2\%20Report.pdf

Sri Lanka Department of Census and Statistics, (2016). Poverty Indicators, Household Income and Expenditure Survey - 2016. Retrieved from http://www.statistics.gov.lk/poverty/Poverty \%20Indicators_2016.pdf

Sri Lanka Department of Census and Statistics, (2017). Household Income and Expenditure Survey - 2016. Retrieved from: http://www.statistics.gov.lk/HIES/HIES201 6/HIES_2016_final_Result.pdf

Ulluwishewa, R. (1991). Modernization versus sustainability: disintegrating village agroecocomplexes in the Dry Zone of Sri
Lanka. Environmental Conservation, 18(2), 103-109.

Unger, J.M., Rauch, A., Frese, M. and Rosenbusch, N. (2011). Human capital and entrepreneurial success: A meta-analytical review. Journal of business venturing, 26(3), 341-358.

Uzun, V. (2005). Large and small business in Russian agriculture: adaptation to market. Comparative Economic Studies, 47(1), 85-100.

Vik, J., \& McElwee, G. (2011). Diversification and the entrepreneurial motivations of farmers in Norway. Journal of small business management, 49(3), 390-410.

Vinayagam, S. (1998) Entrepreneurial behaviour of agri-business operators in Kerala (Doctoral dissertation, Department of Agricultural Extension, College of Horticulture, Vellanikkara).

Walker, E., \& Brown, A. (2004). What success factors are important to small business owners? International small business journal, 22(6), 577-594.

Weerahewa, J., Kodithuwakku, S.S. and Udayanganie, D., 2004. Is agricultural diversification available strategy for improving rural well-being in Sri Lanka? Retrieved from: https://www.researchgate.net/profile/Jeevika _Weerahewa/publication/258205483_Agric ultural_Diversification_in_Sri_Lanka/links/ 567bfc6808ae197583839eeb/AgriculturalDiversification-in-Sri-Lanka.pdf on 26th March 2020.

Weerahewa J, Pushpakumara G, Silva P, Daulagala C, Punyawardena R, Premalal S, Miah G, Roy J et al (2012) Are Homegarden Ecosystems Resilient to Climate Change? An Analysis of The Adaptation Strategies of Homegardeners in Sri Lanka. APN Science Bulletin 2:22-27.

Wijayathilake, G., (2017). Industry Capability Report. Retrieved from: http://www.srilankabusiness.com/pdf/indust ry_capability_reports/floriculture-2017.pdf 